\title{
A Novel Isolation Method for Hen Egg Yolk Antibody, "IgY"
}

\author{
Hajime Hatta, Mujo Kim and Takehiko Yamamoto* \\ Central Research Laboratories, Taiyo Kagaku Co., Ltd., \\ Yokkaichi-shi, Mie 510, Japan \\ *Department of Biotechnology, Fukuyama University, \\ Fukuyama-shi, Hiroshima 729-02, Japan
}

Received February 5, 1990

\begin{abstract}
A method for isolation of egg yolk immunoglobulin, IgG, a livetin protein, was investigated. Several natural gums (carrageenan and xanthan gum) were found to be effective for removal of yolk lipoprotein as a precipitate. The effect was pronounced with $\lambda$-carrageenan and the lipid content in the supernatant after removal of the resulting precipitate was less than $0.4 \%$ of that of egg yolk. IgY remained in this supernatant, with a yield of $86 \%$, and was isolated by chromatography on a column of DEAE-Sephacel followed by salting-out with sodium sulfate. IgY thus isolated was almost pure $(98 \%)$ and the yield was 70 to $100 \mathrm{mg}$ per egg.
\end{abstract}

Antigen-specific immunoglobulin $\mathrm{G}$ ( $\mathrm{IgG}$ ) has been widely used for immunological analysis in the fields of diagonosis as well as pure research. Another important application of IgG is passive immunization therapy in which antigen-specific IgG is administered to unimmunized individuals. IgG has been isolated from sera or colostrum of superimmunized animals such as rabbits, cows, and goats.

Several researchers have demonstrated the effectiveness of passive immunization by oral administration of $\operatorname{IgG}$ for preventing some infectious diseases such as dental caries ${ }^{1)}$ and rotavirus diarrhea. ${ }^{2,3)}$ The practical application of this passive immunization therapy requires the development of a better method of preparing IgG, because large amounts of IgG may be desired. A convenient and large-scale supply of IgG will also promote the use of $\mathrm{IgG}$ for detection or quantitative analysis of various biological substances not only in pharmaceutical but also in cosmetic and food industries.

It is known that the hen transfers her serum IgG to the egg yolk and gives immunity to her offspring. ${ }^{4,5)}$ At present, a tremendous number of hens, immunized to protect them from several diseases, are managed to lay eggs systematically, and the eggs containing IgG are consumed as food. Considering their safety, it may be no problem to use eggs as a source of IgG for oral administration. Therefore, hen eggs seem to be a suitable material for a large-scale production of IgG.

The immunoglobulin of egg yolk which is now called $\mathrm{IgY}{ }^{6}$ ) differs from mammalian IgG in the molecular size (larger), isoelectric point (more acidic), and binding ability with mammalian complement and protein A (no binding ability). ${ }^{7)} \mathrm{IgY}$ is also known as $\gamma$-livetin and exists in egg yok together with other two water-soluble proteins, $\alpha$-livetin (chicken serum albumin) and $\beta$-livetin ( $\alpha_{2}$-glycoprotein) ${ }^{8}{ }^{8}$ and various lipoproteins (LDL and HDL) which are the major components of egg yolk. Therefore, the first step of isolation of $\operatorname{IgY}$ is to separate the water-soluble proteins from lipoproteins. Several methods for isolation of IgY have been reported, ${ }^{9-12)}$ but they are expensive and tedious.

We previously reported a simple method for separation of water soluble proteins of egg yolk using sodium alginate. ${ }^{13)}$ This investigation deals with the effects of various natural gums (food ingredients) on the precipitation of yolk lipoproteins for the preparation of $\mathrm{IgY}$. $\lambda$-Carrageenan was the most effective for 
removal of lipoproteins and on subsequent processing of the supernatant by chromatography and salting-out with sodium sulfate. IgY was obtained in a highly pure state with a yield of $70-100 \mathrm{mg}$ per egg.

\section{Materials and Methods}

Materials. Fresh eggs laid in a local poultry farm (Yokkaichi City) were used. All the natural gums examined (agar, $\kappa-, \lambda, l$-carrageenan, furcellaran, locust bean-, guar-, tamarind-, arabic-, karaya-, and xanthan gum, and sodium alginate) were of food-additive grade. All the reagents used were of chemical grade.

Lipid and protein measurement. The lipid fraction, extracted with chloroform-methanol $(3: 1)$ and evaporated under reduced pressure to dryness, was weighed. For protein measurement, a modification of the method of Markwell et al. ${ }^{14)}$ was used with bovine serum albumin (Sigma) as a reference protein.

SDS-polyacrylamide gel electrophoresis. According to the method of Laemmli, ${ }^{15)}$ polyacrylamide gel electrophoresis with $8-20 \%$ gradient gel (daiichi Pure Chemicals) was done with a slab type vartical gel system. Pre-stained SDS-PAGE standards (Bio-Rad Laboratories), chicken serum albumin, and chicken serum IgG (Sigma) were used as molecular weight markers.

Gel chromatographic analysis. Superose $12 \mathrm{HR}$ prepacked column $(\phi 1.0 \times 30 \mathrm{~cm}$; Pharmacia $)$ was used with the Pharmacia FPLC system. The solvent used was a $50 \mathrm{~mm}$ phosphate buffer containing $150 \mathrm{~mm} \mathrm{NaCl}(\mathrm{pH} 8.0)$, at the flow rate of $0.5 \mathrm{ml}$ per $\mathrm{min}$. The gel chromatographic profile was monitored at $280 \mathrm{~nm}$. Chicken serum albumin and chicken serum $\operatorname{IgG}$ were used as reference proteins.

Immunological measurement. A single radial immunodiffusion plate containing $5 \%(\mathrm{v} / \mathrm{v})$ rabbit antiserum against chicken serum IgG was used to measure the IgY content. Chicken serum IgG was used as a standard. The Ouchterlony method was used to confirm the immunological identity of egg yolk IgY with the chicken srum IgG. Rabbit antiserum against chicken serum IgG was prepared using the ordinary immunization procedure.

\section{Results}

Effects of seveval natural gums on precipitation of yolk lipoprotein

According to the procedure shown in Diagram 1, the effects of several natural gums on precipitation of yolk lipoprotein were

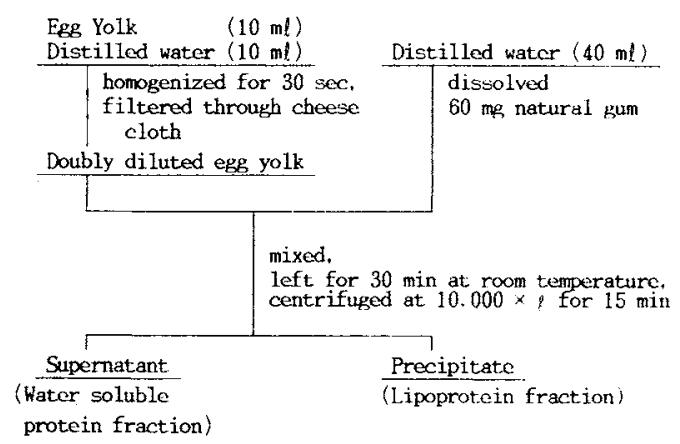

Diagram 1. The Procedure of Separation of Water Soluble Protein and Lipoprotein of Egg Yolk.

Table I. Lipid and Protein Remaining IN THE SUPERNATANT ${ }^{a}$

\begin{tabular}{lcc}
\hline Natural gums, ${ }^{b}$ added & $\begin{array}{c}\text { Remaining } \\
\text { lipid } \\
(\%)\end{array}$ & $\begin{array}{c}\text { Remaining } \\
\text { protein } \\
(\%)\end{array}$ \\
\hline Control & 93.8 & 72.9 \\
Agar & 73.8 & 50.2 \\
$\kappa$-Carrageenan & 0.7 & 16.2 \\
-Carrageenan & 1.1 & 16.2 \\
A-Carrageenan & 0.4 & 20.2 \\
Furcellaran & 3.0 & 18.4 \\
Locust bean gum & 83.6 & 53.6 \\
Guar gum & 93.2 & 55.3 \\
Tamarind gum & 72.2 & 46.0 \\
Arabic gum & 40.2 & 34.9 \\
Karaya gum & 56.3 & 42.5 \\
Xanthan gum & 0.7 & 18.1 \\
Sodium alginate & 4.3 & 20.1 \\
\hline
\end{tabular}

a Refer to Diagram 1.

$b$ The final concentration in the mixture was $0.1 \%$ $(\mathrm{w} / \mathrm{v})$.

investigated. As shown in Table $I$, the supernatant of the control run to which no gums were added contained $93.8 \%$ of the lipid and $72.9 \%$ of the protein of the egg yolk. However, the addition of $\lambda$-carrageenan gave a supernatant containing $0.4 \%$ of the lipid and $20.2 \%$ of the protein. Figure 1 shows the lipoprotein precipitation effect of $\lambda$-carrageenan where the lipoprotein was precipitated at $1,500 \times g$ for $10 \mathrm{~min}$. Similar results were obtained in the case of addition of xanthan gum and some other carrageenans. Furcellaran and sodium alginate were effective next to the above gums. Other gums examined were less, 
Table II. Summary of Purification of IgY from EgG Yolk

\begin{tabular}{|c|c|c|c|c|c|c|c|}
\hline & \multicolumn{2}{|c|}{ Total protein } & \multicolumn{2}{|c|}{ Total lipid } & \multicolumn{2}{|c|}{ Total IgY } & \multirow{2}{*}{$\begin{array}{c}\text { Purity of IgY } \\
(\%)\end{array}$} \\
\hline & $\begin{array}{l}\text { Qty. } \\
\text { (mg) }\end{array}$ & $\begin{array}{l}\text { Yield } \\
(\%)\end{array}$ & $\begin{array}{l}\text { Qty. } \\
\text { (mg) }\end{array}$ & $\begin{array}{l}\text { Yield } \\
(\%)\end{array}$ & $\begin{array}{l}\text { Qty. } \\
\text { (mg) }\end{array}$ & $\begin{array}{l}\text { Yield } \\
(\%)\end{array}$ & \\
\hline Doubly diluted yolk ${ }^{a}$ & 16,000 & $(100)$ & 29,000 & $(100)$ & 790 & $(100)$ & 4.9 \\
\hline Supernatant & 3,500 & $(22)$ & 140 & $(0.5)$ & 680 & $(86)$ & 19.4 \\
\hline Eluate & 1,300 & $(8.1)$ & 0 & & 600 & $(76)$ & 46.2 \\
\hline Salting-out solution & 590 & $(3.7)$ & 0 & & 580 & $(73)$ & 98.3 \\
\hline
\end{tabular}

a The egg yolk used for the purification was $100 \mathrm{~g}$.
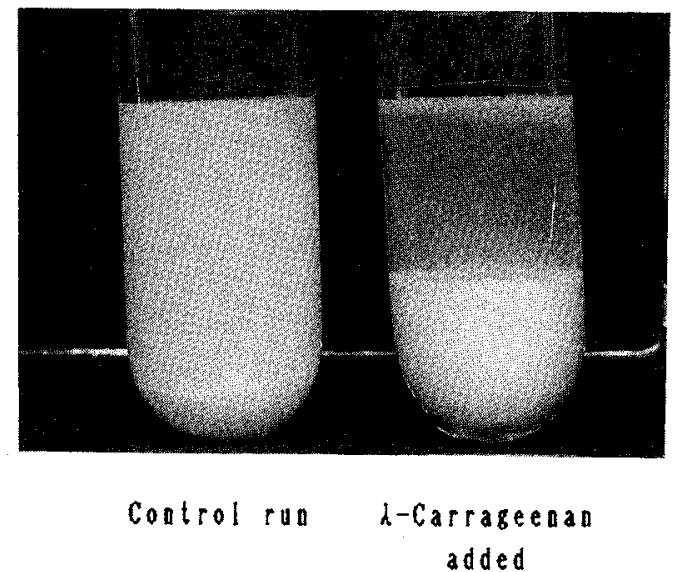

Fig. 1. Effects of Addition of $\lambda$-Carrageenan on Precipitation of Egg Yolk Lipoprotein.

Centrifugation at $1,500 \times g$ for $10 \mathrm{~min}$.

or not effective for removal of egg yolk lipoprotein.

\section{Purification of Ig Y from egg yolk}

The doubly diluted egg yolk $(200 \mathrm{ml})$ was mixed with $400 \mathrm{ml}$ of $0.15 \% \quad \lambda$-carrageenan solution. The mixture was left for $30 \mathrm{~min}$ at room temperature followed by centrifugation at $10,000 \times \dot{g}$ for $15 \mathrm{~min}$. The supernatant was filtered through a filter paper No. 2 (Advantec Toyo). Disodium hydrogenphopshate $(20 \mathrm{~mm})$ was dissolved in this filtrate and the $\mathrm{pH}$ of the mixture was adjusted to 8.0 by adding dropwise $3 \mathrm{~N} \mathrm{HCl}$. The solution was put onto a DEAE-Sephacel column $(\phi 5.0 \times 10.0 \mathrm{~cm}$; Pharmacia) that had previously been equilibrated with $20 \mathrm{~mm}$ phosphate buffer ( $\mathrm{pH} \mathrm{8.0)}$ at a flow rate of $5.0 \mathrm{ml}$ per min. After washing
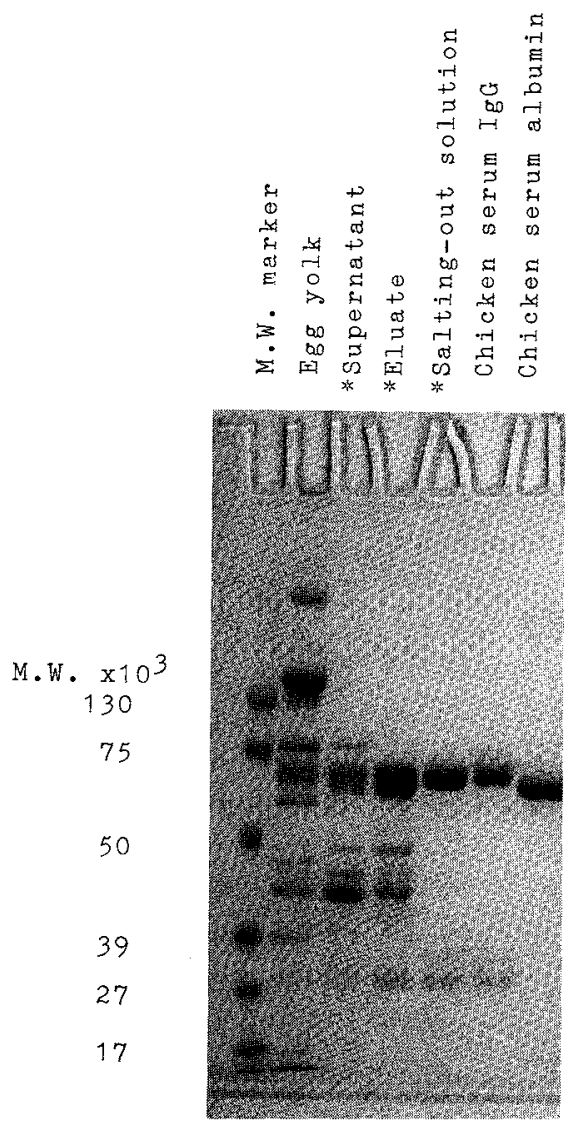

Fig. 2. Electrophoresis of Egg Yolk Proteins Obtained during Purification of $\operatorname{IgY}$.

* Refer to Table II.

Marker proteins: Phosphorylase, $1.3 \times 10^{5}$; BSA, $7.5 \times 10^{4}$; ovalbumin, $5 \times 10^{4}$; carbonic anhydrase, $3.9 \times 10^{4}$; soybean trypsin inhibitor, $2.7 \times 10^{4}$; lysozyme, $1.7 \times 10^{4}$.

the column with the same buffer (twenty volumes of the column), the protein absorbed was eluted with $0.2 \mathrm{M}$ phosphate buffer, $\mathrm{pH} 8.0$, 
(five volumes of the column). The peak fractions checked by monitoring at $280 \mathrm{~nm}$ were collected.

Sodium sulfate, anhydrous powder, was added to the eluate to $15 \%(\mathrm{w} / \mathrm{v})$ at $20^{\circ} \mathrm{C}$. The solution was gently stirred for $30 \mathrm{~min}$ and then, centrifuged at $10,000 \times g$ for $15 \mathrm{~min}$. The resulting precipitate was dissolved in $100 \mathrm{ml}$ of phosphate buffer ( $100 \mathrm{~mm}, \mathrm{pH} 8.0)$. This salting-out procedure was repeated twice more. The final precipitate was dissolved in $100 \mathrm{ml}$ of phosphate buffer ( $10 \mathrm{~mm}, \mathrm{pH} 8.0)$ and dialyzed against the same buffer. The dialyzed solution was filtered through a $0.45 \mu \mathrm{m}$ membrane filter and the filtrate was lyophilized.

The purity of IgY, obtained after three times salting-out with sodium sulfate, was $98.3 \%$ with a yield of $73 \%$ (Table II).

\section{Some properties of the isolated Ig Y}

The purity of IgY was examined by gel chromatography. The IgY finally isolated was homogeneous in size.

The $\operatorname{IgY}$ in the above experiment was also investigated for its electrophoretic patterns by the method of SDS-PAGE system. As shown in Fig. 2, the IgY was pure (under reduced conditions). IgY dissociated into a heavy chain and light chain of $64 \mathrm{kDa}$ and $28 \mathrm{kDa}$. This electrophoretic pattern was in perfect accordance with the IgG isolated from chicken blood

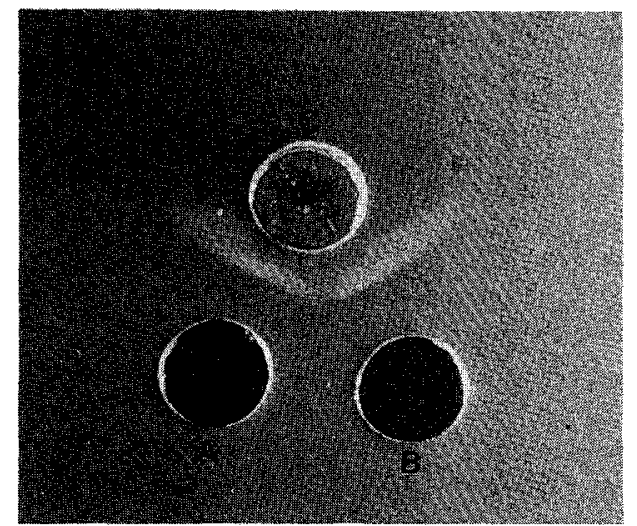

Fig. 3. Ouchterlony Test Showing the Identity of IgY with IgG from Chicken Serum.

A, IgY $(75 \mu \mathrm{g} / 50 \mu \mathrm{l}) ; \mathrm{B}$, chicken serum IgG $(75 \mu \mathrm{g} / 50 \mu \mathrm{l})$; $\mathrm{C}$, rabbit, antiserum against chicken serum $\operatorname{IgG}(50 \mu \mathrm{l})$. serum. The number of proteins obtained in the supernatant, after treating the egg yolk with $\lambda$-carrageenan, were significantly decreased (Fig. 2). The chromatography of this supernatant with DEAE-Sephacel resulted in further purification of $\operatorname{IgY}$. However, the eluate still contained some other proteins that seemed to be $\alpha$ - and $\beta$-livetin. These contaminating proteins were removed by repeated salting-out with sodium sulfate under the conditions described above.

The IgY was also examined for immunological properties. The immunological identity of the IgY matched with the chicken serum IgG (Fig. 3), in which both precipitins against rabbit antiserum were fused.

\section{Discussion}

Egg yolk is an fluid emulsion with a continuous phase of protein (livetins) and a dispersed phase of lipoprotein particles. Yolk lipid thus exists associating with protein as lipoprotein. ${ }^{16)} \mathrm{IgY}$ is one of the livetins ( $\gamma$-livetin). Therefore, removal of the lipoprotein (or lipid) is an important step for the purification of IgY. Many purification methods for IgY based on this strategy have been reported, e.g., lipoprotein separation by ultracentrifugation, ${ }^{9)}$ delipidation by organic solvents, ${ }^{10)}$ and lipoprotein precipitation by polyethyleneglycol ${ }^{11)}$ or sodium dextran sulfate. ${ }^{12)}$ These methods seem to be impractical, because they are uneconomical and troublesome for the large scale preparation of IgY. Moreover, IgY obtained from these methods using organic solvents or chemicals may not be suitable for pharmaceutical purposes.

This paper shows that several natural gums such as carrageenan and xanthan gum are effective as precipitants of yolk lipoproteins. These gums have been used as a food ingredient, so IgY prepared by this method should be suitable for oral administration.

The mechanism of precipitation of yolk lipoprotein by the gums is unknown. It is interesting to note that the effective gums examined in this study were all slightly acidic 
in nature. It may be presumed that the main force causing precipitation with lipoprotein is the ionic binding elaborated between the negative charge of the gums and the net positive charge of the lipoprotein. $\lambda$-Carrageenan was the most effective among the gums examined and the conjugation product was precipitated at low speed centrifugation, $1,500 \times g$ for $10 \mathrm{~min}$, (Fig. 1) avoiding ultracentrifugation.

Hassle et al. reported a comparative study of purification methods of IgY, and even with their best results using polyethyleneglycol (PEG 6,000), the purity of IgY and the yield were $85 \%$ and about $40 \mathrm{mg}$ per egg, respectively. In our study, the yield of $\operatorname{IgY}$ was around $70 \%$ and its net yield amounted to $70-100 \mathrm{mg}$ per egg with the purity of $98 \%$.

The effects of oral administration of antigen-specific IgG have been reported as a promising method for prevention of gastrointestinal or dental infections. The isolation of IgY described in this paper is quite practical and $\mathrm{IgY}$ production from immunized hen eggs may open a new approach to orally administered passive immunization therapy.

\section{References}

I) S. M. Michalek, R. L. Gregory, C. C. Harmon, J. Ketz, G. J. Richardson, T. Hilton, S. J. Filler and J.
R. Mcghee, Infection and Immunity, 55, 2341, (1987).

2) T. Murakami, N. Hirano, A. Inoue, K. Chitose, K. Tsuchiya, K. Ono, Y. Naito and T. Yanagihara, Jpn. J. Vet. Sci., 48, 237 (1986).

3) T. Ebina, A. Sato, K. Umezu, N. Ishida, S. Ohyama, A. Oizumi, K. Aikawa, S. Katagiri, N. Katsushima, A. Imai, S. Kitaoka, H. Suzuki and T. Konno, Med. Microbiol. Immunol., 174, 177 (1985).

4) D. T. Fraser, T. H. Jukes, H. D. Branion and K. D. Halpern, J. Immunol., 26, 347 (1934).

5) R. Patterson, J. S. Youngner, W. O. Weigle and F. J. Dixon, J. Immunol., 89, 272 (1962).

6) G. A. Leslif and L. W. Clem, J. Exp. Med., 130, 1337 (1969).

7) P. S. Gardner and S. Kaye, J. Virol. Methods, 4, 257 (1982).

8) W. G. Martin, J. E. Vandegaer and W. H. Cook, Can. J. Biochem. Physiol, 35, 241 (1957).

9) L. F. McBee and O. J. Cotterill, J. Food Sci., 44, 656 (1979).

10) H. Bade and H. Stegemann, J. Immunol. Methods, 72, 421 (1984).

11) A. Polson and M. B. Von Wechmar, Immunol. Commun, 9, 475 (1980).

12) J. C. Jensenius, I. Anderson, J. Hau, M. Crone and C. Koch, J. Immunol. Methods, 46, 63 (1981).

13) H. Hatta, J. S. Sim and S. Nakai, J. Food Sci., 53, 425 (1988).

14) M. A. K. Markwell, S. M. Hans, L. L. Bieber and N. E. Tolbert, Anal. Biochem., 87, 206 (1978).

15) U. K. Laemmli, Nature, 227, 680 (1970).

16) T. L. Parkinson, J. Sci. Food Agric, 17, 101 (1966).

17) A. Hass1, H. Aspock and H. Flamm, Zbl. Bakt. Hyg., A267, 247 (1987). 